\title{
ASOSIASI CENDAWAN ANTAGONIS TRICHODERMA HARZIANUM RIFAI DAN CENDAWAN MIKORIZA ARBUSKULAR UNTUK MENGENDALIKAN PENYAKIT BUSUK PANGKAL BATANG PADA KEDELAI
}

\author{
Latifah, Hendrival, \& Mihram \\ Program Studi Agroekoteknologi, Fakultas Pertanian, Universitas Malikussaleh \\ Jl. Banda Aceh-Medan, Kampus UNIMAL Cot Teungku Nie, Reuleut \\ Telp. (0645) 57320, Kabupaten Aceh Utara \\ E-mail: latifahmarch@gmail.com
}

\begin{abstract}
Association of antagonistic fungi Trichoderma harzianum Rifai and arbuscular mycorrhizal fungi for controlling the stem rot disease on soybean. The research objective was to study effect of application Trichoderma harzianum and arbuscular mycorrhizal fungi (AMF) in controling stem rot disease caused by Sclerotium rolfsii Sacc on soybean. The research conducted in a Randomized Block Design (RBD) with five treatment levels: (1) without T. harzianum, without AMF, and without $S$. rolfsii [negative control (C-)], (2) without T. harzianum, without AMF, and S. rolfsii [positive control (C+)], (3) T. harzianum + S. rolfsii; (4) AMF $+S$. rolfsii, and (5) T. harzianum $+\mathrm{AMF}+$ S. rolfsii. Parameters observed were basal stem rot disease development and yield components. The results showed that the application of a mixture of T. harzianum and AMF caused a longer disease incubation period (8.29 days) and the severity of stem base rot disease was $11.67 \%$ number of pods per plant (62.53 pods), the number of seeds per plant (225.05 seeds), and the weight of seeds per plant (27.73 g) were higher than that of the application of T. harzianum and AMF separately.
\end{abstract}

Key words: AMF, Sclerotium rolfsii, soybean, T. harzianum

\begin{abstract}
ABSTRAK
Asosiasi cendawan antagonis Trichoderma harzianum Rifai dan cendawan mikoriza arbuskular untuk mengendalikan penyakit busuk pangkal batang pada kedelai. Penelitian bertujuan untuk mengetahui pengaruh aplikasi T. harzianum dan cendawan mikoriza arbuskular (CMA) untuk mengendalikan penyakit busuk pangkal batang yang disebabkan oleh $S$. rolfsii pada kedelai. Penelitian disusun dalam Rancangan Acak Kelompok (RAK) dengan lima taraf perlakuan yaitu (1) tanpa $T$. harzianum, tanpa CMA, dan tanpa S. rolfsii [kontrol negatif(K-)]; (2) tanpa T. harzianum, tanpa CMA, dan S. rolfsii [kontrol positif (K+)]; (3) T. harzianum + S. rolfsii; (4) CMA + S. rolfsii; dan (5) T. harzianum + CMA + S. rolfsii. Parameter yang diamati meliputi perkembangan penyakit busuk pangkal batang dan komponen hasil. Hasil penelitian menunjukkan bahwa aplikasi campuran T. harzianum dan CMA menyebabkan periode inkubasi penyakit lebih lama yaitu 8,29 hari dan tingkat keparahan penyakit busuk pangkal batang lebih rendah yaitu 11,67\% sehingga meningkatkan jumlah polong per tanaman (62,53 polong), jumlah biji per tanaman (225,05 biji), dan berat biji per tanaman (27,73 g) dibandingkan aplikasi T. harzianum dan CMA secara terpisah.
\end{abstract}

Kata kunci: CMA, kedelai, Sclerotium rolfsii, T. harzianum

\section{PENDAHULUAN}

Sclerotium rolfsii menyebabkan penyakit busuk akar, busuk batang, layu, dan busuk pangkal batang pada lebih dari 500 spesies tanaman dalam 100 famili (Cilliers et al., 2000; Davis \& Nunez, 2007). Cendawan ini diketahui menyerang tanaman dikotil seperti kedelai (Saleh \& Hardaningsih, 2007; Sastrahidayat et al., 2010) dan beberapa spesies tanaman monokotil (Davis \& Nunez, 2007). Infeksi $S$. rolfsii pada kedelai biasanya mulai terjadi di awal pertumbuhan tanaman dengan gejala busuk kecambah atau rebah semai. Pada tanaman kedelai berumur yang lebih tua atau 2-3 minggu setelah tanam, gejalanya berupa busuk pangkal batang dan layu, pada bagian terinfeksi terlihat bercak berwarna coklat pucat dan di bagian tersebut tumbuh miselia jamur berwarna putih (Semangun, 1993). Kehilangan hasil kedelai akibat infeksi $S$. rolfsii di Indonesia diperkirakan mencapai 2500 ton/tahun (Rahayu, 2008) dan intensitas kerusakan tanaman kedelai yang terinfeksi patogen tular 
tanah seperti S. rolfsii, Rhizoctonia solani, dan Pythium sp. dapat mencapai 35\% (Sudantha, 1997).

Pengendalian $S$. rolfsii selama ini dilakukan hanya secara mekanis dengan mencabut dan membuang tanaman yang sakit. Cara pengendalian tersebut kurang efektif karena patogen masih mampu bertahan lama di dalam tanah, dengan membentuk organ pembiakan, yaitu sklerotia (Rahayu, 2008). Pengendalian S. rolfsii dapat dilakukan melalui beberapa cara seperti aplikasi fungisida, solarisasi tanah, rotasi tanaman, dan secara hayati (Punja, 1988). Pengendalian hayati dapat dilakukan dengan menggunakan berbagai jenis mikroba yang bersifat antagonis terhadap patogen salah satunya adalah cendawan Trichoderma. Spesies Trichoderma merupakan kelompok cendawan yang mengkolonisasi rizosfir sebagai jenis mikroba yang bersifat antagonis pada patogen tular tanah. Mekanisme antagonis dari spesies Trichoderma adalah persaingan, mikoparasitisme, antibiosis, dan lisis (Benítez et al., 2004). Trichoderma harzianum Rifai mempunyai sifat antagonis terhadap berbagai patogen penyebab penyakit pada tanaman seperti Phytophthora, Pythium, Botrytis, (Benítez et al., 2004), Fusarium spp. (Benítez et al., 2004; Sharma, 2011), Rhizoctonia solani (Gveroska \& Ziberoski, 2011), S. rolfsii (Yaqub \& Shahzab, 2011), dan Colletotrichum falcatum (Singh et al., 2010).

Cendawan mikoriza arbuskular (CMA) merupakan salah satu kelompok cendawan tanah biotrof obligat yang tidak dapat melestarikan pertumbuhan dan reproduksinya bila terpisah dari tanaman inang (Simanungkalit, 2006). Cendawan mikoriza arbuskular memiliki peranan dalam meningkatkan pertumbuhan, meningkatkan serapan hara, pembenah tanah, dan merehabilitasi lahan-lahan terdegradasi (Simanungkalit, 2006) serta sebagai pengendali hayati dalam melindungi akar-akar tanaman dari infeksi patogen tular tanah (Linderman, 1996; Linderman, 2008; Tahat et al., 2008). Inokulasi CMA dapat menekan kejadian penyakit yang disebabkan oleh patogen tular tanah seperti Fusarium sp. pada asparagus (Wacker et al., 1990), tomat (Datnoff et al., 1995), dan kentang (Niemira et al., 1996) serta Verticillium pada terung dan dahlia (Matsubara et al., 1995; Karagiannidis et al., 2002), Phytophthora nicotianae var. parasitica pada tomat (Trotta et al., 1996), dan S. rolfsii pada kacang tanah (Özgönen et al., 2010). Penelitian ini bertujuan untuk mengetahui pengaruh pemberian cendawan antagonis T. harzianum dan cendawan mikoriza arbuskular dalam mengendalikan penyakit busuk pangkal batang yang disebabkan oleh $S$. rolfsii pada kedelai.

\section{METODE PENELITIAN}

Tempat dan Waktu. Penelitian dilaksanakan di Desa Meunasah Baroh, Kecamatan Peudada, Kabupaten Bireuen Propinsi Aceh. dan Laboratorium Agroekoteknologi Program Studi Agroekoteknologi, Fakultas Pertanian Universitas Malikussaleh dari bulan Juli 2012-Januari 2013.

Pelaksanaan Penelitian. Perlakuan dalam percobaan ini disusun dalam bentuk Rancangan Acak Kelompok (RAK) dengan perlakuan asosiasi T. harzianum dan cendawan mikoriza arbuskular yang terdiri dari lima taraf yaitu kontrol negatif (K-) yaitu tanpa T. harzianum, tanpa cendawan mikoriza arbuskular, dan tanpa $S$. rolfsii (T1); kontrol positif $(\mathrm{K}+)$ yaitu tanpa $T$. harzianum, tanpa cendawan mikoriza arbuskular, dan $S$. rolfsii (T2); T. harzianum $+S$. rolfsii (T3); cendawan mikoriza arbuskular $+S$. rolfsii (T4); dan T. harzianum + cendawan mikoriza arbuskular $+S$. rolfsii (T5). Setiap perlakuan terdiri dari tiga ulangan dan setiap ulangan terdapat empat unit tanaman sehingga terdapat 60 satuan percobaan.

Penyediaan dan Perbanyakan Inokulum S. rolfsii. Isolat $S$. rolfsii diisolasi dari tanaman kedelai yang sakit dengan cara bagian tanaman sakit dengan gejala penyakit busuk pangkal batang dibersihkan dari kotoran dengan air steril. Selanjutnya bagian jaringan yang sakit dipotong-potong dengan ukuran 1 x $1 \mathrm{~cm}$, dan di rendam dalam larutan clorox $1 \%$ selama 2 menit, lalu dicuci dengan air steril dan dikeringkan di atas kertas saring steril. Selanjutnya potongan tersebut ditumbuhkan pada media PDA, dan diinkubasi pada suhu ruang. Setelah miselium tumbuh, cendawan diisolasi kembali untuk mendapatkan biakan murni.

Perbanyakan Inokulum T. harzianum. Perbanyakan cendawan $T$. harzianum menggunakan media beras. Beras yang digunakan sebanyak $0,5 \mathrm{~kg}$, kemudian dikukus dalam panci sampai matang. Selesai dikukus, beras tersebut dimasukkan dalam kantung plastik sebanyak $200 \mathrm{~g}$ per kantung dan disterilkan dalam autoclave selama 15 menit pada tekanan 1 atm. Setelah media beras steril dan dingin, biakan murni $T$. harzianum diinokulasikan dengan menggunakan cook borer ukuran $5 \mathrm{~mm}$ ke dalam kantung plastik yang berisi media beras dan diinkubasikan pada suhu $20^{\circ} \mathrm{C}$ selama 14 hari. 
Persiapan Media Tanam. Media tanam yang digunakan adalah tanah dari pertanaman kedelai yang diambil secara komposit pada kedalaman 0-20 cm. Tanah tersebut dikeringanginkan dan dihaluskan serta diayak dengan menggunakan ayakan berdiameter $2 \mathrm{~mm}$. Tanah disterilisasi dengan memasukkan ke dalam tong pengukus dan dikukus selama 2 jam pada suhu $100^{\circ} \mathrm{C}$. Tanah yang telah disterilisasi dimasukkan ke dalam polibag kapasitas $10 \mathrm{~kg}$. Untuk setiap polibag dimasukkan sebanyak $8 \mathrm{~kg}$ tanah dan kemudian disiram hingga kapasitas lapang dan dibiarkan 24 jam. Pupuk kandang diberikan dengan cara dicampur dengan media tanam dengan dosis $10 \mathrm{ton} / \mathrm{ha}$ (50 g/polibag). Benih kedelai sebelum ditanam terlebih dahulu diberi perlakuan benih (seed treatment) dengan cara direndam dalam air panas selama 10-15 menit. Benih ditanam dengan membuat lubang sedalam 3-5 cm, setiap lubang diisi empat benih. Benih kedelai yang digunakan adalah varietas Kipas Merah.

Aplikasi T. harzianum dan Inokulasi S. rolfsii. Aplikasi T. harzianum dilakukan satu minggu sebelum penanaman benih kedelai. Aplikasi T. harzianum diberikan dengan dosis $50 \mathrm{~g} /$ polibag, dicampurkan dengan media tanam.Inokulasi $S$. rolfsii dilakukan bersamaan dengan penanaman benih. Untuk setiap polibag diinokulasikan $S$. rolfsii sebanyak 10 butir sklerotia, yang diberikan di sekeliling lubang tanam benih kedelai.

\section{Inokulasi Cendawan Mikoriza Arbuskular.} Inokulum cendawan mikoriza arbuskular yang digunakan terdiri atas dua spesies yaitu Glomus aggregatum dan Glomus manihotis, diperoleh dari Laboratorium Bioteknologi Hutan dan Lingkungan, Pusat Penelitian Sumberdaya Hayati dan Bioteknologi (PPSHB) Institut Pertanian Bogor. Sumber inokulum CMA yang digunakan adalah berupa zeolit yang bercampur dengan spora, hifa, dan akar terkolonisasi CMA. Pemberian CMA dilakukan secara bersamaan dengan penanaman benih kedelai. Bagian tengah media tanam dibuat lubang sedalam lebih kurang $5 \mathrm{~cm}$ dan ditaburkan $10 \mathrm{~g}$ inokulum CMA dan ditutup dengan selapis tanah, kemudian benih kedelai ditanam.

\section{Perkembangan Penyakit Busuk Pangkal Batang.} Pengamatan perkembangan penyakit busuk pangkal batang meliputi periode inkubasi dan keparahan penyakit busuk pangkal batang. Periode inkubasi penyakit busuk pangkal batang adalah periode antara permulaan infeksi atau inokulasi $S$. rolfsii sampai munculnya gejala yang pertama pada kedelai. Pengamatan keparahan penyakit busuk pangkal batang dilakukan satu minggu setelah inokulasi $S$. rolfsii dengan interval pengamatan dua minggu. Pengamatan terhadap tanaman yang terinfeksi dilakukan dengan cara mengamati gejala yang terlihat dengan menggunakan loupe yaitu pada bagian-bagian pangkal batang yang rusak, yang ditandai dengan perkembangan miselium berwarna putih mengelilingi jaringan tersebut, dan bagian yang terinfeksi tersebut lebih berwarna gelap dan berlekuk. Keparahan penyakit busuk pangkal batang ditentukan dengan rumus berikut (Yusnita et al., 2005).

$$
\text { Keparahan penyakit }=\frac{\sum(\mathrm{n} \times \mathrm{v})}{\mathrm{N} \times \mathrm{Z}} \times 100 \%
$$

keterangan:

$\mathrm{n}=$ jumlah tanaman yang terinfeksi pada setiap kategori

$\mathrm{v}=$ nilai skor dari setiap kategori

$\mathrm{N}=$ jumlah tanaman yang diamati

$\mathrm{Z}=$ nilai skor tertinggi

Nilai skor untuk setiap kategori serangan pada setiap tanaman ditentukan berdasarkan Yusnita et al. (2005) yaitu:

0 = tanpa serangan

$1=$ nekrosis dengan luasan hingga 0,5 lingkar batang

$2=$ nekrosis $0,5-0,75$ lingkar batang

3 = nekrosis telah melingkari batang, muncul bercak coklat yang telah meluas pada permukaan batang yang terinfeksi

4 = seperti pada skor 3 dan batang yang terinfeksi mulai terkulai serta sejumlah daun mulai layu

$5=$ tanaman mati

Perlakuan yang digunakan adalah:

$\mathrm{T} 1=$ Kontrol negarif (K-) [tanpa T. harzianum, tanpa CMA, dan tanpa S. rolfsii]

$\mathrm{T} 2=$ Kontrol positif $(\mathrm{K}+)[\operatorname{tanpa}$ T. harzianum, tanpa CMA, dan $S$. rolfsii]

$\mathrm{T} 3=T$. harzianum $+S$. rolfsii

$\mathrm{T} 4=\mathrm{CMA}+\mathrm{S}$. rolfsii

$\mathrm{T} 5=$ T. harzianum $+\mathrm{CMA}+$ S. rofsii

Komponen Hasil. Pengukuran komponen hasil meliputi jumlah polong per tanaman, jumlah biji per tanaman, dan berat biji per tanaman. Berat biji per tanaman di peroleh dari menimbang biji pada setiap tanaman sampel yang dinyatakan dalam satuan gram (g). Pengamatan komponen hasil dilakukan pada akhir penelitian. 
Analisis Data. Data yang diperoleh dari hasil pengamatan dianalisis dengan menggunakan analisis ragam. Untuk membandingkan rata-rata perlakuan dilakukan dengan uji Beda Nyata Terkecil (BNT) pada taraf 0,05 .

\section{HASIL DAN PEMBAHASAN}

Perkembangan Penyakit Busuk Pangkal Batang. Hasil penelitian menunjukkan bahwa terdapat perbedaan periode inkubasi penyakit busuk pangkal batang dari setiap perlakuan asosiasi cendawan antagonis T. harzianum dan CMA. Aplikasi campuran T. harzianum dan CMA dapat menghambat perkembangan patogen $S$. rolfsii sehingga periode inkubasi lebih lama yaitu 8,29 hari yang secara statistik berbeda nyata dengan aplikasi T. harzianum dan CMA secara terpisah. Aplikasi T. harzianum menyebabkan periode inkubasi lebih lama yaitu 7,12 hari dibandingkan aplikasi CMA yaitu 6,25 hari (Tabel 1). Aplikasi $T$. harzianum, CMA, serta campuran $T$. harzianum dan CMA dapat meningkatkan ketahanan terinduksi tanaman kedelai terhadap penyakit busuk pangkal batang. Aplikasi campuran T. harzianum dan CMA secara terpisah dapat menekan perkembangan penyakit busuk pangkal batang, namun aplikasi campuran $T$. harzianum dan CMA memiliki kemampuan lebih tinggi dalam menekan perkembangan penyakit busuk pangkal batang pada tanaman kedelai. Aplikasi campuran T. harzianum dan CMA menyebabkan periode inkubasi penyakit busuk pangkal batang lebih lama dibandingkan aplikasi $T$. harzianum dan CMA secara terpisah, hal ini diduga karena adanya dominasi dari T. harzianum dan CMA dalam memacu pertumbuhan akar dan menekan perkembangan patogen $S$. rolfsii. Dominasi $T$. harzianum dan CMA di dalam tanah akan membuat lingkungan dan ekologi sekitar tanah menjadi lebih tahan terhadap perkembangbiakan patogen, serta dapat melemahkan serangan patogen lainnya, sehingga kemunculan gejala awal infeksi $S$. roflsii pada tanaman kedelai setelah aplikasi campuran $T$. harzianum dan CMA menjadi lebih lama.

Lambatnya periode inkubasi penyakit busuk pangkal batang pada perlakuan pemberian fungi antagonis $T$. harzianum diduga karena telah terjadi reaksi antara senyawa toksik dari $T$. harzianum terhadap patogen $S$. roflsii. T. harzianum adalah suatu jenis yang baik sebagai pengendali hayati karena terdapat di manamana, mudah diisolasi dan dibiakkan, tumbuh dengan cepat pada beberapa macam substrat, mempengaruhi patogen tanaman, jarang bersifat patogenik pada tanaman tingkat tinggi, bereaksi sebagai mikoparasit, bersaing dengan baik dalam hal makanan, tempat dan menghasilkan antibiotik (Wells, 1988). Selama $T$. harzianum tumbuh aktif menghasilkan sejumlah besar enzim ekstra selular $\beta$ (1.3) glukonase, dan kitinase, yang dapat melarutkan dinding sel patogen (Lewis \& Papavizas, 1984). Mekanisme penghambatan dari $T$. harzianum terhadap infeksi $S$. roflsii dapat terjadi melalui beberapa mekanisme diantaranya dengan memproduksi senyawa gliotoksin dan viridian yang bersifat toksik terhadap cendawan lain (Cook \& Baker, 1983). Mekanisme penghambatan dari T. harzianum terhadap sklerotia dari $S$. roflsii dapat terjadi melalui ultrastruktur. Pertumbuhan dan perkembangan T. harzianum pada sklerotia terjadi bersamaan dengan perubahan sel inang karena mengalami kerusakan pada sitoplasma dan vakuola (Benhamou \& Chet, 1996).

Aplikasi CMA dapat menghambat perkembangan penyakit busuk pangkal batang dengan periode inkubasi

Tabel 1. Pengaruh asosiasi T. harzianum dan CMA terhadap periode inkubasi dan keparahan penyakit busuk pangkal batang

\begin{tabular}{ccccccc}
\hline \multirow{2}{*}{ Asosiasi } & Periode & \multicolumn{5}{c}{ Keparahan penyakit (\%) } \\
\cline { 3 - 7 } T. harzianum dan CMA & inkubasi (hari) & 2 MSI & 4 MSI & 6 MSI & 8 MSI & $10 \mathrm{MSI}$ \\
\hline T2 & 5,16 & $43,33 \mathrm{a}$ & $63,33 \mathrm{a}$ & $68,33 \mathrm{a}$ & $75,00 \mathrm{a}$ & $76,67 \mathrm{a}$ \\
T3 & 7,12 & $23,33 \mathrm{c}$ & $30,00 \mathrm{c}$ & $35,00 \mathrm{c}$ & $26,67 \mathrm{c}$ & $25,00 \mathrm{c}$ \\
T4 & 6,25 & $33,33 \mathrm{~b}$ & $40,00 \mathrm{~b}$ & $43,33 \mathrm{~b}$ & $33,33 \mathrm{~b}$ & $30,00 \mathrm{~b}$ \\
T5 & 8,29 & $11,67 \mathrm{~d}$ & $11,67 \mathrm{~d}$ & $11,67 \mathrm{~d}$ & $11,67 \mathrm{~d}$ & $11,67 \mathrm{~d}$ \\
\hline BNT $(0,05)$ & - & 2,88 & 6,86 & 7,98 & 4,70 & 7,25 \\
\hline KK $(\%)$ & - & 5,17 & 9,47 & 10,09 & 6,42 & 10,13 \\
\hline
\end{tabular}

Angka yang diikuti oleh huruf yang sama dalam satu kolom tidak berbeda nyata berdasarkan uji beda nyata terkecil (BNT) pada taraf 0,05. MSI= minggu setelah inkubasi. 
lebih lama dibandingkan tanpa aplikasi CMA. CMA memiliki pengaruh yang luas terhadap patogen dan mikroba non-patogenik di dalam tanah. Selain berpotensi dalam pengendalian hayati, juga mampu meningkatkan penyerapan hara esensial terutama fosfor $(\mathrm{P})$ oleh akar tanaman. CMA dapat berfungsi sebagai pelindung terhadap infeksi patogen akar dengan mekanisme sebagai berikut (1) adanya selaput hifa (mantel) dapat berfungsi sebagai barier masuknya patogen, (2) mikoriza menggunakan hampir semua kelebihan karbohidrat dan eksudat lainnya, sehingga tercipta lingkungan yang tidak cocok untuk patogen, dan (3) akar tanaman yang sudah diinfeksi fungi mikoriza, tidak dapat diinfeksi oleh fungi patogen yang menunjukkan adanya kompetisi (Imas et al., 1989).

Aplikasi T. harzianum dan CMA baik secara terpisah maupun dicampur sangat efektif dalam menghambat perkembangan penyakit busuk pangkal batang yang disebabkan oleh $S$. rolfsii. Keparahan penyakit busuk pangkal batang mulai diamati pada pengamatan 2 MSI dengan intensitas serangan bervariasi tergantung dari aplikasi T. harzianum dan CMA. Keparahan penyakit busuk pangkal batang pada umur tanaman 2 MSI terendah dijumpai pada aplikasi campuran T. harzianum dan CMA sebesar $11,67 \%$. Penekanan keparahan penyakit busuk pangkal batang oleh asosiasi T. harzianum dan CMA terjadi sampai pada 10 MSI yang secara statistik berbeda nyata dengan aplikasi T. harzianum dan CMA secara terpisah. Aplikasi T. harzianum dan CMA secara terpisah dapat menekan perkembangan penyakit busuk pangkal batang, namun kemampuan penghambatan perkembangan penyakit busuk pangkal batang oleh T. harzianum lebih tinggi dibandingkan dengan CMA. Keparahan penyakit busuk pangkal batang setelah aplikasi T. harzianum secara terpisah mengalami peningkatan pada umur tanaman 2-6 MSI dari 23,33-35\% dan mengalami penurunan pada umur 8-10 MSI dari 26,67-25\%. Keparahan penyakit busuk pangkal batang setelah aplikasi CMA secara terpisah juga mengalami peningkatan pada umur tanaman 2-6 MSI dari 33,33$43,33 \%$ dan penurunan pada umur tanaman 8-10 MSI dari 35,83-33,33\%. Keparahan penyakit busuk pangkal pada kedelai yang tidak diaplikasikan dengan T. harzianum dan CMA mengalami peningkatan yang tajam sejak 2-10 MSI dengan tingkat keparahan penyakit mencapai 43,33-76,67\% (Tabel 1).

Kemampuan campuran T. harzianum dan CMA lebih dominan dalam menekan perkembangan patogen $S$. rolfsii sehingga meningkatkan ketahanan terinduksi pada tanaman kedelai dibandingkan dengan kemampuan secara mandiri. T. harzianum merupakan cendawan antagonis yang memiliki potensi dalam pengendalian secara hayati terhadap cendawan patogen seperti $S$. rolfsii. CMA dapat meningkatkan pertumbuhan tanaman dan berinteraksi dengan dengan mikroorganisme lainnya yang dijumpai pada rizofir (Ocampo, 1993) seperti T. harzianum. CMAdiketahui memiliki peran dalam pengendalian penyakit pada tanaman yang disebabkan oleh patogen tular tanah (Xavier \& Boyetchko, 2004). Kehadiran kedua di dalam tanah dapat menghambat perkembangan $S$. rolfsii dan meningkatkan ketahanan terinduksi terhadap penyakit busuk pangkal batang. Hasil penelitian tentang aplikasi campuran $T$. harzianum dan CMA untuk pengendalian patogen telah banyak dilaporkan antara lain oleh Arriola et al. (2000) yang melaporkan bahwa aplikasi T. harzianum dan CMA (Glomus intraradices) efektif mengendalikan penyakit busuk akar pada tanaman asparagus yang disebabkan oleh Fusarium oxysporum f. sp. asparagi. Haggeg et al. (2001) juga melaporkan bahwa interaksi antara CMA (Glomus mosseae) dengan T. harzianum dapat menghambat perkembangan penyakit busuk akar pada tanaman Geranium yang disebabkan oleh Fusarium solani dan Machrophomine phaseoline. Selain itu, Arýcý et al. (2010) melaporkan bahwa aplikasi T. harzianum dan CMA (Glomus mosseae) dapat menekan kejadian penyakit dampingoff yang disebabkan oleh $F$. culmorum pada tanaman gandum, dan Mwangi et al. (2011) melaporkan bahwa aplikasi T. harzianum dan CMA efektif mengendalikan penyakit layu yang disebabkan oleh Fusarium oxysporum f. sp. lycopersici pada tomat di pembibitan.

T. harzianum merupakan cendawan antagonis yang memiliki potensi dalam pengendalian secara hayati terhadap cendawan patogen seperti Botrytis cineria, Fusarium, Pythium, dan Rhizoctonia (Khetan, 2001). Mekanisme antagonis cendawan Trichoderma spp. dalam menekan cendawan patogen, yaitu sebagai mikoparasit, kompetitor yang agresif dan antibiosis. Mula-mula pertumbuhan miselia cendawan Trichoderma spp. memanjang, kemudian membelit dan mempenetrasi hifa cendawan inang, sehingga hifa inang mengalami vakoulasi, lisis dan akhirnya hancur. Selanjutnya antagonis ini tumbuh di dalam hifa patogen. Chet \& Baker (1980 dalam Cook \& Baker, 1983) melaporkan bahwa cendawan T. harzianum dan T. hamatum bertindak sebagai mikoparasit terhadap cendawan Rhizoctonia solani dan Sclerotium rolfsii, menghasilkan enzim $\beta-(1,3)$ glucanase dan chitinase yang menyebabkan eksolisis pada hifa inang.

Aplikasi CMA dapat menekan perkembangan penyakit busuk pangkal batang yang disebabkan oleh $S$. rolfsii pada tanaman kedelai. Secara umum peran CMA 
dalam pengendalian patogen tanaman adalah adanya perubahan pada anatomi dan morfologi akar yang berasosiasi dengan CMA, perubahan populasi mikroba disekitar rizosfir tanaman yang berasosiasi dengan CMA, dan pengaktifan mekanisme pertahanan tanaman oleh adanya asosiasi dengan CMA (Azcón-Aguilar \& Barea, 1996). Sedangkan secara spesifik misalnya adanya aktivitas enzim-enzim yang berperan dalam biosintesis lignin (peroksidase dan polifenol oksidase) maupun enzim hidrolitik (kitinase dan glukanase), adanya pembentukan struktur seperti papila maupun deposisi material seperti kalus terutama pada tempat terjadinya infeksi patogen (Cordier et al., 1998; Pozo et al., 2002; Lee et al., 2005; Zheng et al., 2005). Hasil penelitian tentang pemanfaatan CMA untuk pengendalian patogen telah banyak dilaporkan antara lain oleh Cordier et al. (1998) dan Pozo et al. (2002) melaporkan bahwa aplikasi CMA (G. mosseae) efektif mengendalikan Phytophthora parasitica pada tanaman tomat. Hashim (2003) melaporkan bahwa aplikasi mikoriza efektif menekan kematian akibat $G$. boninense pada kelapa sawit, Khaosaad et al. (2007) melaporkan bahwa aplikasi CMA secara sistemik mampu menekan Gaeumannomyces graminis var. tritici pada tanaman barlei, dan Ozgonen et al. (2010) bahwa CMA efektif untuk pengendalian busuk batang yang disebabkan oleh $S$. rolfsii pada kacang tanah.

Komponen Hasil. Hasil penelitian menunjukkan bahwa terdapat perbedaan komponen hasil dari setiap perlakuan asosiasi cendawan antagonis T. harzianum dan CMA. Aplikasi campuran T. harzianum dan CMA dapat meningkatkan komponen hasil kedelai seperti jumlah polong per tanaman sebesar 62,53 polong, jumlah biji per tanaman sebesar 225,05 biji, dan berat biji per tanaman sebesar 27,73 g yang secara statistik berbeda nyata dengan aplikasi $T$. harzianum dan CMA secara terpisah (Tabel 2). Aplikasi CMA secara terpisah menghasilkan komponen hasil yang secara statistik tidak berbeda nyata dengan aplikasi T. harzianum. Aplikasi T. harzianum, CMA, serta campuran $T$. harzianum dan CMA dapat menghambat perkembangan dan meningkatkan ketahanan terinduksi tanaman kedelai terhadap penyakit busuk pangkal batang sehingga meningkatkan komponen hasil kedelai dibandingkan dengan tanpa aplikasi $T$. harzianum dan CMA.

Aplikasi T. harzianum dan CMA dapat menekan perkembangan patogen $S$. rolfsii dan meningkatkan komponen hasil kedelai. Hasil penelitian menunjukkan bahwa aplikasi cendawan antagonis T. harzianum dapat dikombinasikan dengan CMA karena dapat mempercepat pertumbuhan dan perkembangan tanaman serta menekan perkembangan penyakit busuk pangkal batang. Kemampuan T. harzianum dan CMA lebih dominan dalam memacu pertumbuhan akar dan menekan perkembangan patogen $S$. rolfsii sehingga meningkatkan ketahanan terinduksi pada tanaman kedelai. Ketahanan terinduksi merupakan ketahanan tanaman terhadap infeksi patogen karena tanaman telah terinfeksi oleh mikroorganisme lain sebelumnya, baik dari jenis yang sama maupun dari jenis lain. Cendawan endofit adalah cendawan yang hidup di dalam jaringan tanaman sehat tanpa menyebabkan gejala atau kerusakan pada tanaman inang (Davis et al., 2003) seperti CMA, sedang cendawan saprofit antagonis adalah cendawan yang hidup pada sisa-sisa bahan organik dan mempunyai kemampuan menekan pertumbuhan cendawan patogen tular tanah. Peranan T. harzianum adalah mengeluarkan enzim selulosa yang mampu merombak dinding sel patogen, sehingga patogen

Tabel 2. Pengaruh asosiasi T. harzianum dan CMA terhadap jumlah polong per tanaman, jumlah biji per tanaman, dan berat biji per tanaman

\begin{tabular}{cccc}
\hline $\begin{array}{c}\text { Asosiasi } \\
\text { T. harzianum dan CMA }\end{array}$ & Jumlah polong per tanaman & Jumlah biji per tanaman & Berat biji per tanaman (g) \\
\hline T1 & $44,94 \mathrm{~b}$ & $146,01 \mathrm{~b}$ & $17,12 \mathrm{~b}$ \\
T2 & $22,55 \mathrm{c}$ & $67,66 \mathrm{c}$ & $4,86 \mathrm{c}$ \\
T3 & $46,72 \mathrm{~b}$ & $148,49 \mathrm{~b}$ & $16,41 \mathrm{~b}$ \\
T4 & $46,75 \mathrm{~b}$ & $151,25 \mathrm{~b}$ & $18,02 \mathrm{~b}$ \\
T5 & $62,53 \mathrm{a}$ & $225,05 \mathrm{a}$ & $27,73 \mathrm{a}$ \\
\hline BNT $(0,05)$ & 7,29 & 18,84 & 2,22 \\
\hline KK $(\%)$ & 8,67 & 6,77 & 7,01 \\
\hline
\end{tabular}

Angka yang diikuti oleh huruf yang sama dalam satu kolom tidak berbeda nyata berdasarkan uji beda nyata terkecil (BNT) pada taraf 0,05. 
mati dan tanaman akan rentan terhadap penyakit. $T$. harzianum juga mengeluarkan substansi kimia atau hormon yang didifusikan ke dalam jaringan tanaman kedelai yang dapat memacu pertumbuhan akar. Windham et al. (1986) melaporkan bahwa cendawan T. harzianum dapat meningkatkan perkecambahan benih dan pertumbuhan tanaman.

Aplikasi CMA secara terpisah dapat meningkatkan serapan hara sehingga menghasilkan pertumbuhan akar yang lebih baik dan dapat menekan penyakit busuk pangkal batang. CMA mampu meningkatkan pertumbuhan tanaman karena status hara tanaman tersebut dapat ditingkatkan dan diperbaiki. Kemampuan dalam meningkatkan penyerapan air dan hara terutama P cukup tinggi (Smith \& Read, 2007; Bryla \& Duniway, 1997). Seperti dijelaskan oleh Sieverding (1991) bahwa CMA yang menginfeksi sistem perakaran tanaman inang akan memproduksi jalinan hifa secara intensif sehingga tanaman bermikoriza akan mampu meningkatkan kapasitasnya dalam menyerap unsur hara dan air, karena CMA dapat menaikkan luas permukaan penyerapan sistem perakaran. CMA dapat berfungsi sebagai pelindung biologi bagi terjadinya infeksi patogen akar melalui lapisan hifa (mantel) dapat berfungsi sebagai pelindung fisik untuk masuknya patogen.

Aplikasi T. harzianum pada tanaman kedelai berfungsi sebagai agens hayati terhadap patogen $S$. rolfsii dan stimulator pertumbuhan tanaman sehingga menghasilkan komponen hasil kedelai lebih tinggi dibandingkan tanpa aplikasi T. harzianum. Cendawan antagonis $T$. harzianum merupakan cendawan penghuni tanah yang dapat diisolasi dari perakaran tanaman yang dapat meningkatkan pertumbuhan tanaman. Seperti menurut Salisbury \& Ross (1995) yang menyatakan bahwa beberapa jenis jamur yang hidup di tanah dapat menghasilkan etilen. Diduga etilen yang dilepaskan oleh jamur tersebut membantu mendorong perkecambahan biji, mengendalikan pertumbuhan kecambah, memperlambat serangan organisme patogen tular tanah, dan memacu pembentukan bunga. Pengaruh etilen dalam jaringan dapat meningkatkan sintesis enzim, jenis enzimnya bergantung pada jaringan sasaran. Jika jamur patogenik tertentu menyerang sel, etilen menginduksi tanaman untuk membentuk dua jenis enzim yang menguraikan dinding sel jamur patogen yaitu $\beta-(1,3)$ glucanase dan chitinase (Boller, 1988 dalam Salisbury \& Ross, 1995), sehingga etilen dapat mengaktifkan mekanisme ketahanan induksi tanaman terhadap patogen penyebab penyakit seperti $S$. rolfsii.

Jumlah polong, jumlah biji, dan berat biji per tanaman pada perlakuan yang diinfeksikan patogen $S$. rolfsii tanpa aplikasi $T$. harzianum atau CMA lebih rendah dibandingkan aplikasi T. harzianum atau CMA. Hal ini menunjukkan bahwa pertumbuhan akar terhambat atau mengalami gangguan dan hambatan bila telah terinfeksi oleh patogen penyebab penyakit. Seperti yang diungkapkan oleh Agrios (2005) bahwa tumbuhan dikatakan sehat atau normal apabila dapat melaksanakan fungsi-fungsi fisiologisnya sesuai dengan potensial genetik terbaik yang dimiliki, meliputi pembelahan, diferensiasi, dan perkembangan sel, penyerapan dan translokasi air dan mineral, fotosintasis dan memobilisasi hasilnya, metabolisme, reproduksi, serta penyimpanan. Apabila tumbuhan diganggu oleh patogen maka salah satu atau lebih dari fungsi tersebut juga akan terganggu.

\section{SIMPULAN}

Aplikasi campuran T. harzianum dan CMA menyebabkan periode inkubasi penyakit lebih lama yaitu 8,29 hari dan tingkat keparahan penyakit busuk pangkal batang lebih rendah yaitu $11,67 \%$. Jumlah polong per tanaman (62,53 polong), jumlah biji per tanaman $(225,05$ biji), dan berat biji per tanaman $(27,73 \mathrm{~g})$ lebih tinggi dibandingkan pada aplikasi $T$. harzianum dan CMA secara terpisah.

\section{SANWACANA}

Ucapan terima kasih disampaikan kepada Yusmaini, S.P. (Laboratorium Ilmu Penyakit Tanaman Fakultas Pertanian Universitas Syiah Kuala) yang telah membantu pelaksanaan penelitian.

\section{DAFTAR PUSTAKA}

Agrios GN. 2005 Plant Pathologi, 5th edition. Elsivier Academic Press, San Diego, California.

Arýcý SE, Eser I, \& Özgönen H. 2010. Effect of Trichoderma harzianum and an arbuscular mycorrhizal fungus Glomus Mosseae on fusarium crown rot (Fusarium culmorum) in wheat (Cv Altay 2000). In: 2nd International Symposium on Sustainable Development, June 892010 , Sarajevo.

Arriola LL, Hausbeck MK, Rogers J, \& Safir GR. 2000. The effect of Trichoderma harzianum and Arbuscular Mycorrhizae on Fusarium root rot in Asparagus. Horttechnology 10(1): 141-144. 
Azcon-Aguilar C \& Barea JM. 1996. Arbuscular mycorrhizas and biological control of soil-borne plant pathogens - an overview of the mechanisms involved. Mycorrhiza 6: 457-464.

Benhamou N \& Chet I. 1996. Parasitism of sclerotia of Sclerotium rolfsii by Trichoderma harzianum: ultrastructural and cytochemical aspects of the interaction. Phytopathology 86(4): 405-416.

Benitez T, Rincon AM, Limon MC, \& Codon AC. 2004. Biocontrol mechanisms of Trichoderma strains. Int Microbiol 7(4): 249-260.

Bryla DR \& Duniway JM. 1997. Effects of mycorrhizal infection on drought tolerance and recovery in safflower and wheat. Plant Soil 197: 95-103.

Cilliers, AJ, Herselman L, \& Pretorius ZA. 2000. Genetic variability within and among mycelial compatibility groups of Sclerotium rolfsii in South Africa. Phytopathology 90(9): 1026-1031.

Cordier C, Pozo MJ, Barea JM, Gianinazzi S, \& Gianinazzi-Pearson V. 1998. Cell defense responses associated with localized and systemic resistance to Phytophthora parasitica induced in tomato by an arbuscular mycorrhizal fungus. Mol Plant-Microbe Int 11(10): 1017-1028.

Cook RJ \& Baker KF. 1983. The Nature on Practice of Biological Control of Plant Pathogens. The American Phytopathological Society, ABS press. St. Paul, Minesota.

Datnoff LE, Nemec S, \& Pernezny K. 1995. Biological control of Fusarium crown and root rot of tomato in Florida using Trichoderma harzianum and Glomus intraradices. Biol. Control 5(3): 427431.

Davis EC, Franklin JB, Shaw AJ \& Vilgalys R. 2003. Endophytic Xylaria (Xylariaceae) among liverworts and angiosperms: phylogenetics, distribution, and symbiosis Am. J. Bot. 9(11): 1661-1667.

Davis MR \& Nunez J. 2007. Integrated approaches for carrot pests and diseases management. In: Ciancio A \& Mukerji KG. (Eds.). General Concepts in Integrated Pest and Disease Management. pp.149-190.
Gveroska B \& Ziberoski J. 2011. The influence of Trichoderma harzianum on reducing root rot disease in tobacco seedlings caused by Rhizoctonia solani. Int. J. Pure Appl. Sci. Tech. 2(2): 1-11.

Haggag WM, Latif A, \& Faten M. 2001. Interaction between vasicular arbuscular mycorrhizae and antagonistic biocontrol microorganisms on controlling root-rot disease incidence of geranium plants. J. Biol. Sci. 1(12):1147-1153.

Hashim A. 2003. Ganoderma versus mycorrhiza. Oil Palm Bull. 47: 6-14.

Imas T, Hadioetomo RS, Gunawan AW, \& Setiadi Y. 1989. Mikrobiologi Tanah II. Depdikbud Ditjen Dikti, Pusat Antar Universitas Bioteknologi, IPB, Bogor.

Karagiannidis N, Bletsos F, \& Stavropoulos N. 2002. Effect of Verticillium wilt (Verticillium dahliae Kleb.) and mycorrhiza (Glomus mosseae) on root colonization, growth and nutrient uptake in tomato and eggplant seedlings. Sci. Hort. 94(1-2): 145156.

Khaosaad T, Garcia-Garrido JM, Steinkellner S, Vierheilig H. 2007. Take-all disease is sistemically reduced in roots of mycorrhizal barley plants. Soil Biol. Biochem. 39(3): 727-734.

Khetan SK. 2001. Microbial Pest Control. Marcel Dekker, Inc. Basel, New York.

Lee CS, Lee YJ, \& Jeun YC. 2005. Observations of infection structures on the leaves of cucumber plants pre-treated with arbuscular mycorrhiza Glomus intraradices after challenge inoculation with Colletotrichum orbiculare. Plant Pathol. J. 21(3): 237-243.

Lewis JA \& Papavizas GC. 1984. A new approach to stimulate population proliferation of Trichoderma species and other potential biocontrol fungi introduced into natural soils. Phytopathology 74(10): 1240-1244.

Linderman RG. 1996. Role of VAM fungi in biocontrol. In: Pleger FL \& Linderman RG (Eds.). Mycorrhizae and Plant Health. pp. 1-25. APS Press, St Paul, Minnesota. 
Linderman RG. 2008. The mycorrhizosphere phenomenon. In: Feldman F, Kapulnik Y, \& Barr J (Eds.).Mycorrhiza Works. pp 341-355. Deutsche Phytomedizinische Gesellschaft, Braunschweig, Germany.

Matsubara Y, Tamura H, \& Harada T. 1995. Growth enhancement and Verticillium wilt control by vesicular-arbuscular mycorrhizal fungus inoculation in eggplant (Solanum melongena). J. Japan Soc. Hort. Sci. 64(3): 555-561.

Mwangi MW, Monda EO, Okoth SA, \& Jefwa JM. 2011. Inoculation of tomato seedlings with Trichoderma harzianum and arbuscular mycorrhizal fungi and their effect on growth and control of wilt in tomato seedlings. Braz. J. Microbiol. 42(2): 508-513.

Niemira BA, Hammerschmidt R, \& Safir GR. 1996. Postharvest suppression of potato dry rot (Fusarium sambucinum) in prenuclear minitubers by arbuscular mycorrhizal fungal inoculum. Am. Potato J. 73: 509-515.

Ocampo JA. 1993. Influence of pesticides on VA mycorrhiza. In: Altman J. (Ed.). Pesticide-plant pathogen interactions in crop production: beneficial and deleterious effects. pp. 214-226. CRC Press, Boca Raton, FL.

Ozgonen H, Akgul DS, \& Erkilic A. 2010. The effects of arbuscular mycorrhizal fungi on yield and stem rot caused by Sclerotium rolfsii Sacc. in peanut. Afr. J. Agric. Res. 5(2): 128-132.

Pozo MJ, Cordier C, Dumas-Gaudot E, Gianinazzi S, Barea JM, \& Azcon-Aguilar C. 2002. Localized versus systemic effect of arbuscular mycorrhizal fungi on defence responses to Phytophthora infection in tomato plants. J. Exp. Bot. 53(368): 525-534.

Punja ZK. 1988. Sclerotium (Athelia) rolfsii APathogen of Many Plant Species. In: Sidhu GS (Ed.). Advances in Plant Pathology. Vol. 6 Genetics of Plant Pathogenic Fungi. pp. 523-534. Academic Press, London.

Rahayu M. 2008. Efikasi isolat Pseudomonas fluorescens terhadap penyakit rebah semai pada kedelai. Penelitian Pertanian Tanaman Pangan 27(3): 179-184.
Saleh N \& Hardaningsih S. 2007. Pengendalian penyakit terpadu pada tanaman kedelai. Dalam: Sumarno, Suyamto, Widjono A, Hermanto, \& Kasim H (Eds). Kedelai: Teknik Produksi dan Pengembangan. pp. 319-344. Pusat penelitian dan Pengembangan Tanaman Pangan, Badan Penelitian dan Pengembangan Pertanian, Bogor.

Salisbury FB \& Ross CW. 1995. Fisiologi Tumbuhan Jilid 3. Perkembangan Tumbuhan dan Fisiologi Tumbuhan. Terjemahan DR Lukman dan Sumaryono. Penerbit ITB Bandung. Bandung.

Sastrahidayat R, Sulistyowati L, Djauhari S, Muhibuddin A. \& Saleh N. 2010. Biocontrol of Sclerotium rolfsii (caused damping-off disease) on soybean varieties using Streptomyces sp. and arbuscular mycorrhizal fungi. In: Proceeding of The 8th International Symposium on Biocontrol and Biotechnology. pp. 83-91. October 4-6, 2010 Pattaya, Thailand.

Semangun H. 1993. Penyakit-Penyakit Tanaman Pangan di Indonesia. Gadjah Mada University Press. Yogyakarta.

Sharma P. 2011. Complexity of Trichoderma-Fusarium interaction and manifestation of biological control. Aus. J. of Crop Sci. 5(8): 1027-1038.

Sieverding E. 1991. Vesicular Arbuscular Mycorrhiza Managemment, Technical Cooperation Federal Republik of German, Eschborn.

Simanungkalit RDM. 2006. Cendawan mikoriza arbuskuler. Dalam: Simanungkalit RDM, Suriadikarta DA, Saraswati R, Setyorini D, \& Hartatik W (Ed.). Pupuk Organik dan Pupuk Hayati. pp. 159-190. Badan Penelitian dan Pengembangan Pertanian. Balai Besar Litbang Sumberdaya Lahan Pertanian, Bogor.

Singh V, Singh PN, Yadav RL, Awasthi SK, Joshi BB, Singh RK, Lal RJ, \& Duttamajumder SK. 2010. Increasing the efficacy of Trichoderma harzianum for nutrient uptake and control of red rot in sugarcane. J.Hort.For. 2(4): 66-71.

Smith SE \& Read DJ. 2007. Mycorrhizal Symbiosis. Academic Press. San Diego. 
Sudantha IM. 1997. Pengendalian patogen tular tanah pada tanaman kedelai secara hayati menggunakan bahan organik dan Trichoderma harzianum. Dalam: Prosiding Kongres Nasinal XIV dan Seminar Nasional. Perhimpunan Fitopatologi Indonesia. Palembang.

Tahat MM, Kamaruzaman S, Radziah O, Kadir J, \& Masdek HN. 2008. Respon of (Lycopersicum esculentum Mill.) to different arbuscular mycorrhizal fungi species. Asian J.Plant Sci. 7(5): 479-484.

Trotta A, Varese GC, Gnavi E, Fusconi A, Sampo S, \& Berta G. 1996. Interactions between the soilborne root pathogen Phytophthora nicotianae var. parasitica and the arbuscular mycorrhizal fungus Glomus mosseae in tomato plants. Plant Soil 185: 199-209.

Wacker TL, Safir GR, \& Stephens CT. 1990. Effect of Glomus fasciculatum on the growth of asparagus and the incidence of fusarium root rot. J. Amer. Soc. Hort. Sci. 115(4):550-554.

Wells HD. 1988. Trichoderma as biocontrol agent. In: Mukerj KG \& Garg KL (ed.). Biocontrol of Plant Diseases. pp. 71-82. CRC Press, New York.
Windham MT, Elad Y \& Baker R. 1986. A mechanism of increased plant growth induced by Trichoderma spp. Phytopathology 76(5): 518521.

Xavier LJC \& Boyetchko SM. 2004. Arbuscular mycorrhizal fungi in plant disease control. In: Arora DK (ed.). Fungal Biotechnology in Agricultural, Food, and Environmental Applications. pp. 183-194 Dekker, New York.

Yaqub F \& Shahzad S. 2011. Efficacy and persistence of micobial antagonists against Sclerotium rolfsii under field conditions. Pak. J. Bot. 43(5): 2627 2634.

Yusnita, Widodo, \& Sudarsono. 2005. In vitro selection of peanut somatic embryos on mediun containing cultur filtrate of Sclerotium rolfsii and plantlet regeneration. Hayati 12(2): 50-56.

Zheng HZ, Cui CL, Zhang YT, Wang D, Jing Y, \& Kim KY. 2005. Active changes of lignification-related enzymes in pepper response to Glomus intraradices and/or Phytophthora capsici. J Zhejiang. Univ. Sci. 6(8): 778-786. 